\title{
多段階載荷の三軸圧縮試験のモデル化と その適用性の検討
}

\author{
木村 誠 $^{1}$ ・谷 和夫 $^{2}$ ・岡田哲実 ${ }^{3}$ \\ 1 学生会員 横浜国立大学大学院 工学府（†240-8501 横浜市保土ヶ谷区常盤台 79-5) \\ 2 Ph.D. 横浜国立大学大学院 工学研究院（テ240-8501 横浜市保士ヶ谷区常盤台 79-5) \\ ${ }^{3}$ 正会員 工修 (財) 電力中央研究所 地圈環境部 (T270-1194 我孫子市我孫子 1646)
}

\begin{abstract}
岩石の単段階载荷の三軸圧縮試験 (Single-step loading triaxial compression test:以下 SL-TCT) では, せん断強 度定数を得るために複数の供試体が必要である.これに対して, 多段階載荷の三軸圧縮試験 (Multiple-step loading triaxial compression test:以下 ML-TCT) は, 1 本の供試体で複数の拘束圧に対するせん断強さが得られるので時間 的にも経済的にも有利である. しかし, 軸圧縮 (せん断)を繰り返すことによって供試体に損傷が蓄積して発揮される せん断強さが低下するメカニズムが明らかではないため, SL-TCT の代替方法としての地位が確立されてはいない. そこで, ML-TCTをシミュレーションすることが可能な多段階载荷損傷モデル (Multiple-step loading damage model) を作成し, ML-TCT において軸圧縮(せん断)を行う拘束圧の設定数と順序について検討した.
\end{abstract}

Key Words : triaxial compression test, rock, shear strength, strain

1. はじめに

岩石のせん断強度特性を評価するために行われて いる室内試験は, 通常, 1本の供試体に対して1つの拘 束圧を作用させて軸圧縮 (せん断)を1回だけ行う単段 階載荷の三軸圧縮試験 (Single-step loading triaxial compression test: 以下 SL-TCT と称す)である ${ }^{1}$. 地盤 材料のせん断強さは拘束圧に強く依存するため, ある 試料のせん断強度特性を把握するためには複数の供 試体に対してそれぞれ異なる拘束圧を設定して SL-TCT を何回も行う必要がある. ところが実際には, 調查対象の岩石を代表する同じような性質の供試体を, 設定する拘束圧の数だけ採取することが困難な場合が ある.このような問題に対処するため, 1 本の供試体に 対して複数の拘束圧を設定し, 各拘束圧の下で軸圧縮
(せん断)を行ってせん断強さを求める多段階載荷の三 軸圧縮試験 (Multiple-step loading triaxial compression test:以下 ML-TCT と称す) が Kovari \& Tisa (1975)によ って提案された ${ }^{2)}$.

表-1 は,この ML-TCT と一般に行われている SL-TCT を比較したものである. ML-TCT は, 必要な供 試体の本数が少なく, 場合によっては, たった 1 本の供 試体からせん断強度特性を評価することも可能である. そのため, 試料の不均質性 (供試体同士の相違) や供 試体の設置の相違によるデータのばらつきを避けること ができるといら利点がある. しかし，以下に示すように， ML-TCT にはいくつかの問題点が指摘されているため に, 標準となる試験方法は確立していないし, その普及 度も低い.

表- 1 単段階载荷と多段階载荷の三軸圧縮試験の比較

\begin{tabular}{|c|c|c|}
\hline & $\begin{array}{c}\text { 単段階載荷の三軸圧縮試験 } \\
\text { (SL-TCT) }\end{array}$ & $\begin{array}{c}\text { 多段階載荷の三軸圧縮試験 } \\
\text { (ML-TCT) }\end{array}$ \\
\hline $\begin{array}{c}\text { 強度特性を求めるために } \\
\text { 必要な供試体の本数 }\end{array}$ & $\begin{array}{c}\text { 拘束圧ごとに供試体が必要 } \\
\text { 通常, } 4 \text { 本以上 }\end{array}$ & 最低 1 本の供試体で良い \\
\hline 試験データのばらつき & 大きい & 小さい \\
\hline $\begin{array}{c}\text { 軸圧縮 (せん断) 前の } \\
\text { 応力履歴 } \\
\end{array}$ & $\begin{array}{c}\text { 通常, 等方圧密のみ } \\
\text { 軸圧縮 (せん断)の履歴はない }\end{array}$ & $\begin{array}{l}\text { 拘束圧ごとに軸圧縮するので, 後段の } \\
\text { 軸圧縮 (せん断)ほど損傷が蓄積する }\end{array}$ \\
\hline 試験方法の基準 & $\begin{array}{l}\text { 地盤工学会基淮 (岩石の UU 条件, } \\
\text { 軟岩の CU 条件, 軟岩の CD 条件) }\end{array}$ & 整備されていない \\
\hline
\end{tabular}




\section{2. 多段階載荷の三軸圧縮試験の問題点}

SL-TCTでは1つの拘束圧の下で 1 回しか軸圧縮 (せ ん断)しないが, ML-TCT では複数の拘束圧に対する せん断強さを求めるために軸圧縮 (せん断)を繰り返し ている. 一番の問題は, この応力履歴によって供試体 が損傷(せん断強さの低下の原因となるダメージ)を受 けてしまい, 後段の軸圧縮 (せん断) ほどせん断強さが 過小評価される愁念があることである. 損傷の程度は， 採用する応力経路, 寸なわち供試体の応力履歷に依 存する(図-1). ML-TCT の応力履歴に影響を与えるフ

a)
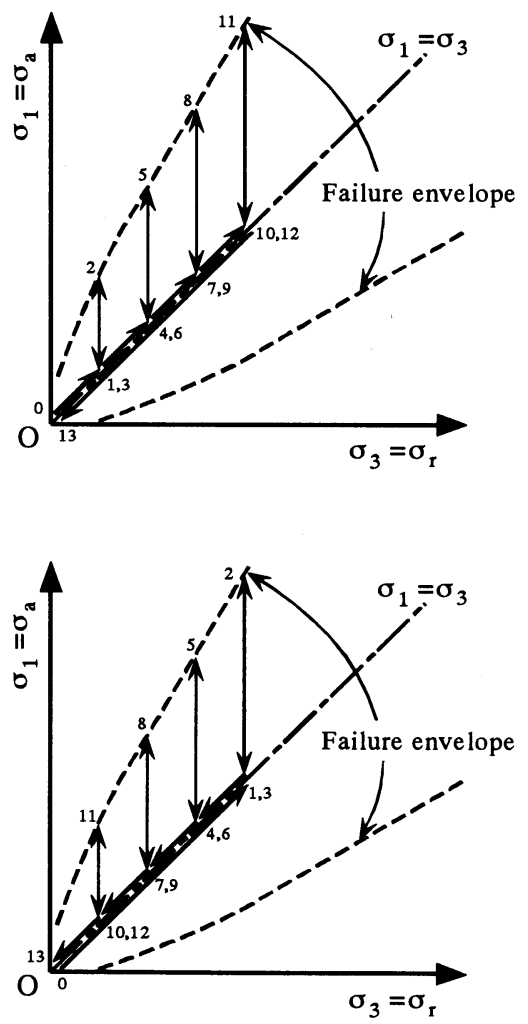

e)

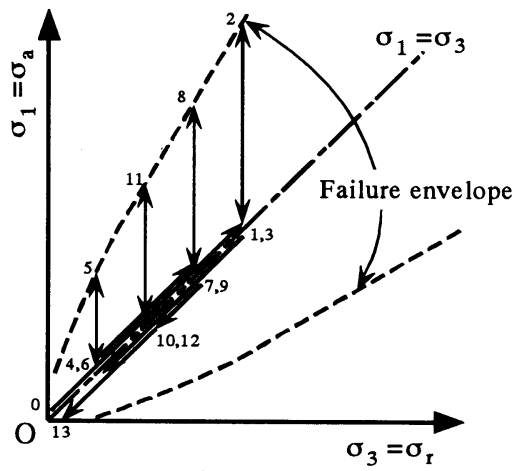

アクターは, 軸圧縮 (せん断)を行う拘束圧の設定数と順 序, せん断除荷と次段階への圧密の方法, さらにピーク の判定方法の合計3つである.

\section{（1）軸圧縮（せん断）を行う拘束圧}

最も一般的な応力経路は, 軸圧縮 (せん断)ごとに等 方圧密状態までせん断除荷してから次段階の圧密を行 い, 設定した 4 種類程度の拘束圧を順次増加させるもの である(図-1 a ) .

a) 軸圧縮（せん断）を行う拘束圧の設定数 図-1bに示すように, 設定する拘束圧の数が多いと,

b)

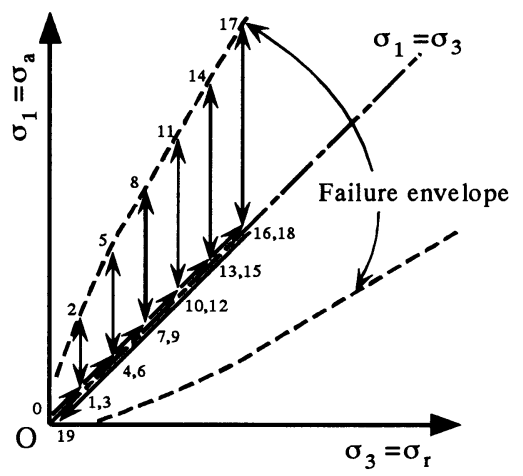

d)

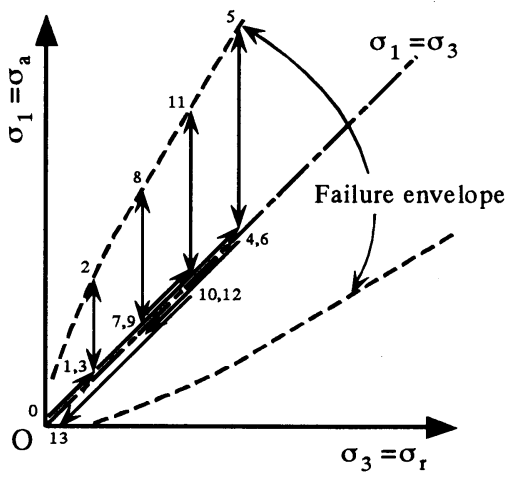

f)

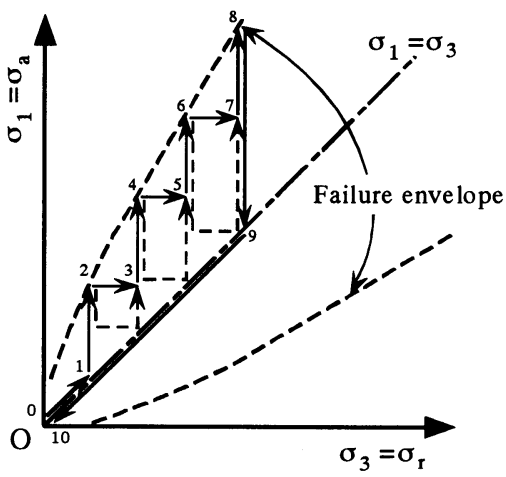

図-1 多段階载荷の三軸圧縮試験における応力履歴の例 
供試体に累積する損傷が増大して，せん断強さに与え る影響が大きいと懸念される. しかし, 拘束圧の設定数, すなわち軸圧縮 (せん断)の回数と, 累積する損傷によ って発揮されるせん断強さがどのように変わるかを調べ た研究はほとんどない.

\section{b）軸圧縮（せん断）を行う拘束圧の順序}

既往の研究では, 低い拘束圧から高い拘束圧一と段 階的に上げていく方法が多い. 他にも高い拘束圧から 低い拘束圧一段階的に下げていく方法(図-1c)や，ラ ンダムに拘束圧を設定する方法 (図-1 d や図-1e ) が 採用されることもある ${ }^{2,3)}$. 軸圧縮 (せん断)を行う拘束圧 の順序の影響や, 最適な順序を検討した研究事例は非 常に少ない.

\section{（2）せん断除荷と次段階への圧密の方法}

軸圧縮 (せん断)ごとに等方圧密状態までせん断除 荷 (完全除荷)し, それから次段階の圧密を行う方法 (図 -1abcde)だけではない. 他にも, ピークに達したら直ち にセル圧を次段階の拘束圧に上昇させる方法(図-1f の実線)や, 軸応力を次段階の拘束圧まで除荷 (不完 全除荷)してからセル圧を次段階の拘束圧に上昇させ

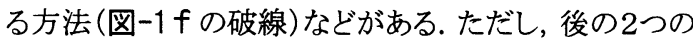
方法は, 低い拘束圧から高い拘束圧一と段階的に上げ ていく場合にしか適用することができない. また, せん断 除荷を完全に行う方が, 軸圧縮 (せん断) 前の圧密が適 切に行えることが指摘されている ${ }^{3), 4}$.

\section{（3）ピークの判定方法}

各拘束圧の下でピーク（主応力差が最大となる時点） を判定する確立された基準は存在しない. ピークを確実 に確認しようとすると, 軟化現象が始まって, すなわちピ 一クを過ぎてから軸圧縮 (せん断)を停止するので供試 体が被る損傷は大きくなりやすい. 逆に, 何らかの手段 でピークが近いことを判定して, 実際にピークのせん断 強さが発揮される手前で軸圧縮 (せん断)を停止すると, 本来のせん断強さを過小評価してしまう.このピークが 近いことを推定する手段には, 主応力差と軸ひずみの 関係 ${ }^{5,6}, \mathrm{AE}$ の発生 ${ }^{7)}$, 過剩間隙水圧の挙動 ${ }^{4), 8}$ を利用 した例がある. しかし, 計測の負担が増え, 判定の信頼 性や岩種の影響など解決すべき問題が多い.

\section{3. 研究の目的と検討の方法}

\section{(1) 研究の目的}

岩盤は一般に不均質で不連続なので, ばらつきのな い岩石供試体を何個も用意して SL-TCT を行い, 信頼 度の高い強度特性を得ることが非常に難しい. したがっ
て, 少ない供試体で SL-TCT と同等のせん断強度特性 を評価できる可能性がある ML-TCT に対する期待は大 きい.さらにSL-TCT に比較して ML-TCT は時間的に も経済的にも有利な手法である点も見逃せない.この ML-TCT が SL-TCT の代替方法として確立されるため には, 前章に示すように, 何回も軸圧縮 (せん断)を行う ことによる応力履歷の影響を明らかにする必要がある. すなわち, 軸圧縮 (せん断)の繰り返しに伴って損傷が 蓄積すると共に, 発揮されるせん断強さが低下する劝 ニズムを調べる必要がある.

そこで,これまで研究事例がほとんどなかった, 軸圧 縮 (せん断)を行う拘束圧の設定数と順序について検討 した. なお本研究では, せん断強さを確実に把握するた めに軟化の開始を確認してから軸圧縮(せん断)を停止 し, 圧密を確実に行うために等方応力状態まで完全除 荷してから次段階の圧密を行う方法を採用した.

\section{（2）検討の方針}

上記の検討を行う方法には2種類が考えられる. 1 つ は, 軸圧縮 (せん断)を行う拘束圧の数や順序を幅広く 変えた ML-TCT を数多く行い, その結果を比較・検討 する方法である. 試験データに基づいているので, 得ら れた結果の信頼性が高いという利点があるのに対し, デ 一タがばらつく可能性があることや，検討の効率が悪い という久点を有する. また, 累積する損傷の程度と発揮 されるせん断強さのメカニズムを理解しないと, 検討した 岩種に限定された結論しか得られない(結論の一般性 に欠ける)ので, 合理的ではない.

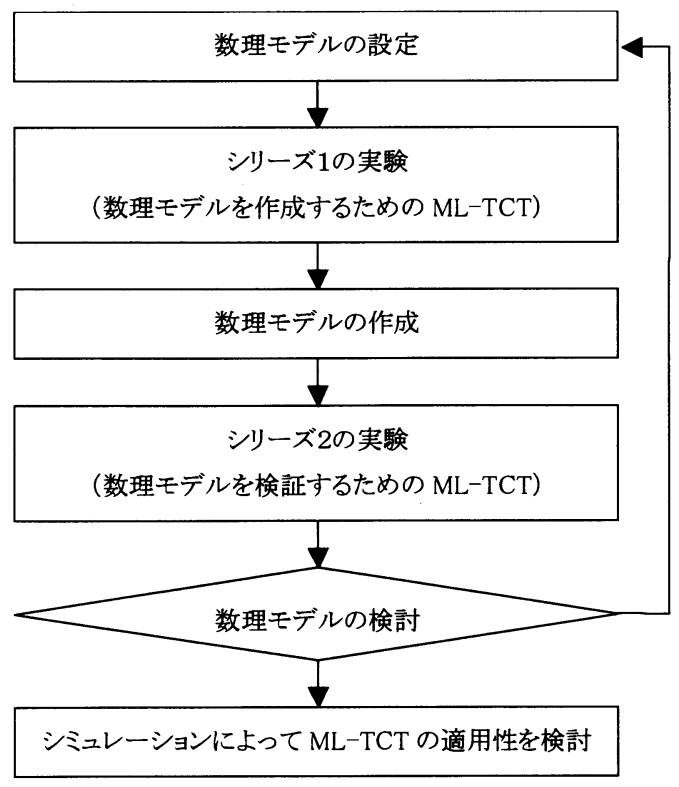

図-2 検討のフロー 
もう1つは, 検討の項目が考虑できる数理モデルを作 成する方法である. この数理モデルを利用して, 軸圧縮 （せん断）を行う拘束圧の数や順序を幅広く変えた ML-TCTのシミュレーションを行って, その結果を比較・ 検討する. 数理モデルの妥当性を検証する必要がある が, 累積した損傷の程度と発揮されるせん断強さのメカ ニズムをきちんとモデル化できれば, 合理的であり, 検 討の効率も良い.

本研究では, その合理性を重視して, 後者の数理モ デルによる検討方法を選択した. 図-2 に示すように, 検 討のフローは2つの実験シリーズより成っている ${ }^{9)}$. シリ ーズ1の実験は，ある岩種に対する数理モデルを作成 するための ML-TCT である. この数理モデルをシリーズ 2の実験として実施する ML-TCT に対して適用して，そ の妥当性を検証する. そして最後に, 数理モデルを用 いたシミュレーションによって ML-TCT の適用性を検討 する.

\section{（3）検討に用いた試料}

試料には, 供試体のばらつきによる影響を最小にす るため, 均質・塊状で, 粒度が細かい堆積軟岩を用いた. 新第三紀鮮新世後期の海成の堆積軟岩で, 仙台層群 上部の大年寺層の上部層から $40 \mathrm{~cm}$ 角にブロックサンプ リングした. 粉砕した試料の粒度分析 (日本工業規格 JIS A 1204)の結果を図-3 に示す. 工学的分類(地盤工 学会基準 JGS 0051)は高液性限界のシルト(MH,塑性 指数 $\left.I_{\mathrm{p}}=20.9\right)$ に属するので, 以後, シルト岩と称する.

このシルト岩は非常に均質で連続であるので, 直径 が 10〜 500 mm の円柱供試体を用いた三軸圧縮試験の 結果で寸法効果は認められなかった ${ }^{10)}$. そこで, 直径 $50 \mathrm{~mm}$, 高さ $100 \mathrm{~mm}$ に整形した供試体を用いて全ての 実験を行った.

シリーズ1とシリーズ2の実験で，それぞれ7本と2本 の供試体を用いた. その物理特性は湿潤密度 $\rho_{\mathfrak{t}}=$ $1.72 \sim 1.79\left(\mathrm{~g} / \mathrm{cm}^{3}\right)$, 含水比 $w=46.3 \sim 49.3(\%)$ で, 超 音波速度は $V_{s}=474 \sim 532(\mathrm{~m} / \mathrm{sec}), V_{\mathrm{p}}=1266 \sim 1493$ $(\mathrm{m} / \mathrm{sec})$ であった. 比較的に含水比が高く, 軟質で固結 度も低い岩石である.

\section{4. 多段階載荷の三軸圧縮試験の数理モデル （多段階載荷損傷モデル）の概念}

基本となる SL-TCT のせん断強度特性に, 繰り返し 軸圧縮 (せん断)を行うことにより供試体に蓄積する損傷 の影響を考慮して ML-TCT のせん断強度特性を表現 する数理モデルを考案した. この多段階載荷損傷モデ ル(Multiple-step loading damage model)を, 以後, MLD

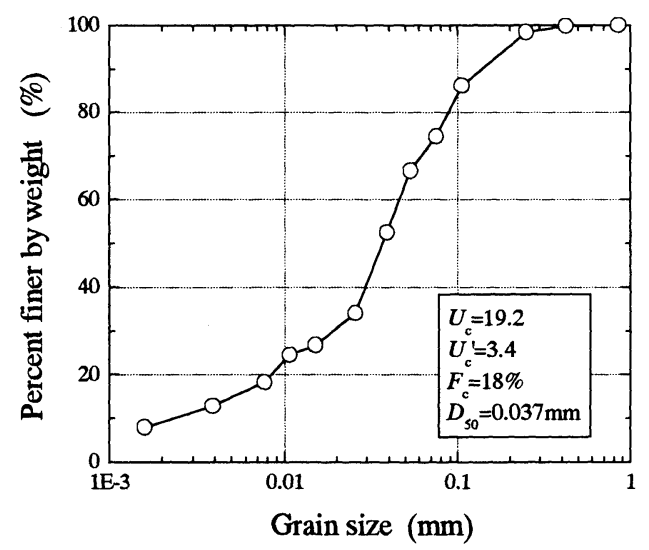

図-3 粉砕したシルト岩の粒度分析の結果

モデルと称する.なお, 三軸圧縮試験は圧密非排水せ ん断 (CU 条件)を対象とした.

\section{(1) MLD モテルの概念}

まず基本となる SL-TCT のせん断強度特性は, 一般 に破壊時の最大主応力 $\sigma{ }^{\prime}{ }_{1 \mathrm{f}}$ と最小主応力 $\sigma{ }^{\prime}{ }_{3 \mathrm{f}}$ の組み 合わせで表現される. 三軸圧縮試験では, 有効拘束圧 $\sigma{ }^{\prime}$ に対するせん断強さ (最大主応力差) $q=\sigma^{\prime}{ }_{1 \mathrm{f}}$ $\sigma{ }^{\prime}{ }_{3 \mathrm{f}}$ とピーク時の過剩間隙水圧 $u=\sigma{ }^{\prime}-\sigma{ }^{\prime}{ }_{3 \mathrm{f}}$ の関係 に置き換えることができる.よって, SL-TCT のせん断強 さ(最大主応力差) $q_{\mathrm{SL}}$ とピーク時の過剩間隙水圧 $u_{\mathrm{SL}}$ を 有効拘束圧 $\sigma{ }^{\prime}{ }_{\mathrm{c}}$ の関数として与えた.

次に, ML-TCT で繰り返し軸圧縮(せん断)を行うこと によって, 後段の載荷段階で発揮されるせん断強さが 影響を受ける現象を考慮しなければならない. そこで, ある載荷段階までに供試体が受けた損傷の程度を代表 するパラメータとして, 完全にせん断除荷した後 (せん 断応力がゼロに戻った時)に残留していた塑性軸ひず み $\varepsilon \mathrm{a}^{\mathrm{p}}$ を採用した. 一般に, 地盤材料の構成関係では, 硬化パラメータを塑性体積ひずみにする場合が多いが, 岩石の三軸圧縮試験で体積ひずみを精度良く計測す ることは難しく、塑性軸ひずみで代用することとした.

その結果, SL-TCT のせん断強度特性の表現に倣い, ML-TCT のせん断強度特性を, せん断強さ(最大主応 力差) $q_{\mathrm{ML}}$ とピーク時の過剩間隙水圧 $\boldsymbol{u}_{\mathrm{ML}}$ を有効拘束圧 $\sigma{ }_{\mathrm{c}}$ と塑性軸ひずみ $\varepsilon{ }_{\mathrm{a}}^{\mathrm{p}}$ の関数として与えることができ る. また, 軸圧縮 (せん断) 履歴によって, どの程度の損 傷が蓄積するのかを推定する関係も必要である. そこで, ある載荷段階 ( $\mathrm{i}$ 回目)による塑性軸ひずみの增分 $\Delta \varepsilon{ }_{\mathrm{a}}{ }_{\mathrm{i}} \mathrm{i}$ を、有効拘束圧 $\sigma^{\prime}{ }_{\mathrm{c}}$ とその載荷段階の前 (i-1 回 目)までに累積した塑性軸ひずみ $\varepsilon_{\mathrm{a}}^{\mathrm{p} i-1}$ の関係で与え た. 
(2) MLD モデルの構成と ML-TCT のシミュレーション の方法

MLD モデルを構成する5つの関倸の概念を図-4に 示す.

(1) SL-TCT のせん断強さ (最大主応力差) $q_{\mathrm{SL}}$ を有効 拘束圧 $\sigma^{\prime}{ }_{\mathrm{c}}$ より推定する関係で, (2)の関係と合わせ れば破壊基準と等価である.

(2) SL-TCT のピーク時の過剩間隙水圧 $u_{\mathrm{SL}}$ を有効拘 束圧 $\sigma^{\prime}{ }_{\mathrm{c}}$ より推定する関係で, ダイレイタンシー特性 を反映している.

(3) ML-TCT の i 回目の載荷段階で発揮されるせん断 強さ (最大主応力差) $q_{\mathrm{ML}, \mathrm{i}}$ と SL-TCT のせん断強さ (最大主応力差) $q_{\mathrm{SL}}$ 之の比 $q_{\mathrm{ML}, \mathrm{i}} / q_{\mathrm{SL}}$ を, 有効拘束圧 $\sigma^{\prime}{ }_{c}$ と $(i-1)$ 回目の載荷段階までに累積した塑性軸 ひずみ $\varepsilon_{\mathrm{a} \text {-1 } 1}^{p_{2}}$ より推定する関係である. 多段階載荷 の履歷がせん断強度特性に及ぼす影響を表してい る.

(4) ML-TCT の $\mathrm{i}$ 回目の載荷段階のピーク時の過剩間 隙水圧 $u_{\mathrm{ML}, \mathrm{i}}$ と SL-TCT のピーク時の過剩間隙水圧 $u_{\mathrm{SL}}$ との比 $u_{\mathrm{ML}, i} / u_{\mathrm{SL}}$, 有効拘束圧 $\sigma{ }^{\prime}{ }_{\mathrm{c}}$ と (i-1) 回目 の載荷段階までに累積した塑性軸ひずみ $\varepsilon_{\mathrm{a}}^{\mathrm{p}-1-1}$ より

a)

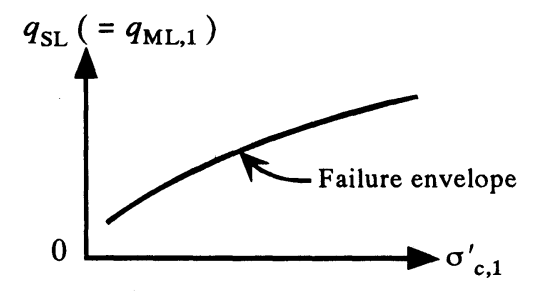

b)

$$
u_{\mathrm{SL}}\left(=u_{\mathrm{ML}, 1}\right)
$$

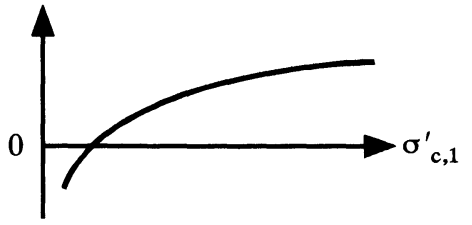

図-4 MLD モデルを構成する5つの関係
$\mathrm{a}$ :(1)の関係 $\left(\mathrm{SL}-\mathrm{TCT}\right.$ の $q_{\mathrm{SL}} \sim \sigma^{\prime}{ }_{\mathrm{c}}$ )
$\mathrm{b}:$ (2)の関倸 $\left(\mathrm{SL}-\mathrm{TCT}\right.$ の $\left.u_{\mathrm{SL}} \sim \sigma^{\prime}{ }_{\mathrm{c}}\right)$
c: (3)の関係 $\left(\mathrm{ML}-\mathrm{TCT}\right.$ の $\left.q_{\mathrm{ML}, \mathrm{i}} / q_{\mathrm{SLi}} \sim \sigma{ }^{\prime}, \varepsilon_{\mathrm{a}}{ }_{\mathrm{i}-1}\right)$
$\mathrm{d}$ :(4)の関係 (ML-TCT $u_{\mathrm{ML}, \mathrm{i}} / u_{\mathrm{SL}} \sim \sigma{ }^{\prime}, \varepsilon_{\mathrm{a}}^{\mathrm{P}_{\mathrm{i}-1}}$ )

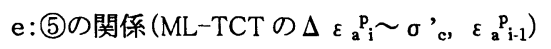

推定する関係である. 多段階載荷の履歴がダイレイ タンシー特性に及ぼす影響を表している.

(5) ML-TCT の i回目の載荷段階による塑性軸ひずみ の增分 $\Delta \varepsilon \varepsilon_{\mathrm{a}}{ }_{\mathrm{i}}^{\mathrm{p}}$ を、有効拘束圧 $\sigma{ }^{\prime}{ }_{c}$ と $(\mathrm{i}-1)$ 回目の載 荷段階までに累積した塑性軸ひずみ $\varepsilon_{\mathrm{a} i-1}^{\mathrm{p}}$ より推定 する関係である. 軸圧縮 (せん断) 履歷による損傷の 受けやすさを表している.

この MLD モデルの特徴は, 多段階に載荷する応力 履歷によって蓄積される損傷を, 累積する塑性軸ひず み $\varepsilon_{\mathrm{a}}^{\mathrm{p}}$ で代表させた点である.この $\varepsilon_{\mathrm{a}}^{\mathrm{p}}$ は, 各載荷段階 でせん断が終了した後, 等方圧密状態にまで完全除荷 をして, さらに排水状態として供試体内の過剩間隙水圧 を消散させて軸圧縮 (せん断) 前の応力状態に戻った 時点で計測した.

図-4 に示す MLD モデルを用いることによって, ML-TCT をシミュレーションすることできる. そのシミュレ ーションのフローを図-5に示す. ML-TCTのi段階目の 軸載荷 (せん断) がある有効拘束圧 $\sigma{ }^{\prime}$ c で行われた場 合に, 発揮されるせん断強さ $q_{\mathrm{ML}, \mathrm{i}}$ は(1)と(3)の関係, ピ 一ク時の過剩間隙水圧 $u_{\mathrm{ML}, \mathrm{i}}$ は(2)と(4)の関係によって推 定することができる. そして,この i 段階目の軸圧縮 (せ

c)

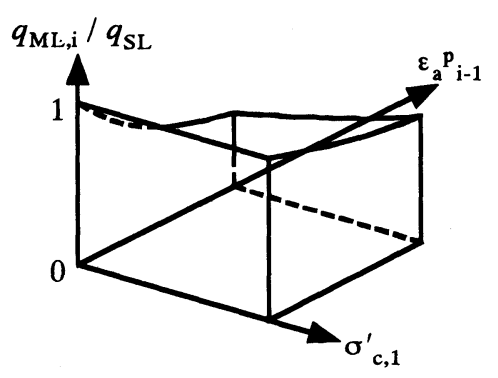

d)

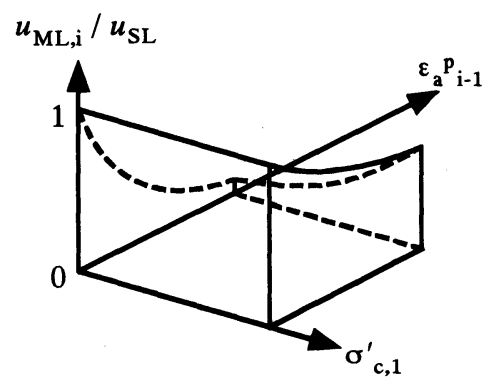

e)

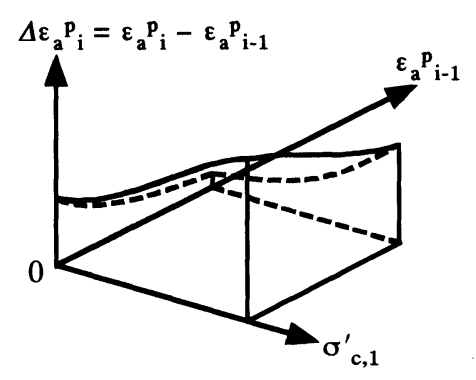




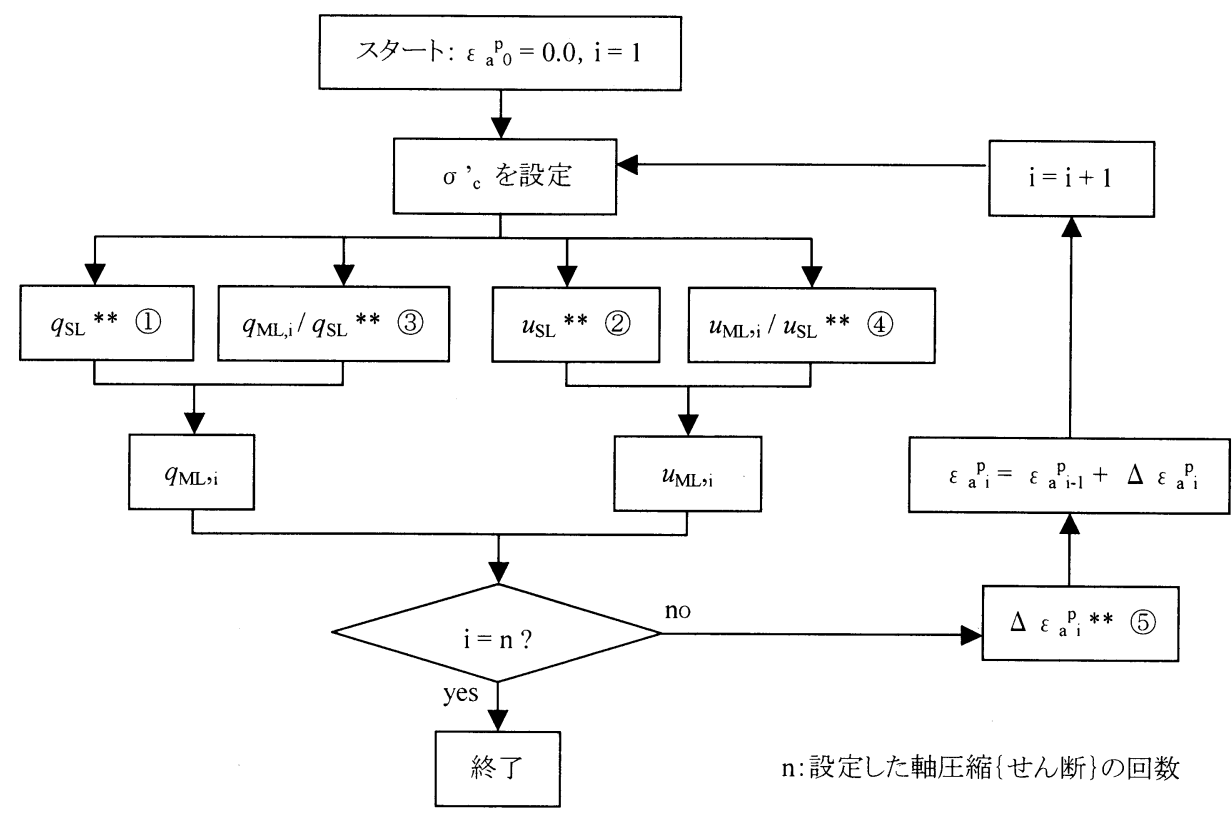

図-5 MLD モデルによる ML-TCT のシミュレーション

ん断)によって新たに供試体に蓄積した塑性軸ひずみ 増分 $\Delta \varepsilon \varepsilon_{\mathrm{a}}{ }_{\mathrm{i}}{ }_{\text {}}$ は, (5)の関係によって評価することができ る.

\section{（3）MLD モデルの適用性の検討}

ここで注意すべきことは， $q_{\mathrm{ML}, \mathrm{i}} / q_{\mathrm{SL}}, u_{\mathrm{ML}, \mathrm{i}} / u_{\mathrm{SL}}$, $\Delta \varepsilon{ }_{\mathrm{a}}{ }_{\mathrm{i}}^{\mathrm{p}}$ を $\sigma^{{ }_{\mathrm{c}}}{ }_{\mathrm{c}}$ と $\varepsilon_{\mathrm{a}}{ }_{\mathrm{i}-1}^{\mathrm{p}}$ から推定寸る(3)〜(5)の関係が, 軸 圧縮 (せん断) を行う拘束圧の設定数や順序に依存しな いことを仮定している点である.この仮定が正しければ, ML-TCT における軸圧縮 (せん断) の回数や順序に関 して,いかなる条件も図-5に示すフローによってシミュレ ーションが可能である.

そこで, (3)〜 (5)の関係が軸圧縮 (せん断)を行う拘束 圧の設定数や順序に依存しないことを確かめるため, 図-2 に示すように, 2つのシリーズの実験を行った.ま ず, シルト岩に対する MLD モデルを作成するために、 ある特定の拘束圧の設定で ML-TCT (シリーズ1の実 験)を実施した. そして同じシルト岩に対して, シリーズ1 と異なる拘束圧の設定で ML-TCT (シリーズ2の実験) を行った.このシリーズ2の実験結果と, シリーズ1の実 験結果に基づく MLD モデルを用いてシリーズ2の ML-TCT をシミュレーションした結果とを比較した. そし て, シミュレーションの結果が実験の結果を良好に再現 できているのであれば、MLD モデルの適用性が高いと 判断することとした.

\section{5. シルト岩に対する MLD モデルの作成（シリ ーズ 1 の実験)}

\section{（1）検討の方法}

シルト岩に対して, MLD モデルを構成する(1)〜(5)の 関係(図-4)を求めるために行う実験 (シリーズ1)である. 拘束圧の設定に関しては, 図-6 に示すように同じ拘束 圧で軸載荷 (せん断) /完全除荷と再圧密を繰り返す 応力経路を選択した. 供試体の相違による実験データ のばらつきの影響を受けずに, 各拘束圧の下で軸圧縮 (せん断)の回数が増えて損傷が蓄積するのに伴って せん断強さやピーク時の過剩間隙水圧が変化する傾向 が直接に把握でき, (3)〜 (5)の関係が効率的に得られる からである. また, SL-TCT に関する(1)と(2)の関係は, 最初の載荷段階 $(\mathrm{i}=1)$ に対する結果を利用することが できるので, 別途 SL-TCTを実施する必要はない，すな わち, $q_{\mathrm{SL}}=q_{\mathrm{ML}, 1}, u_{\mathrm{SL}}=u_{\mathrm{ML}, 1}$ とする.

\section{（2）実験の方法と条件}

多段階に軸載荷をすることを除いて, 基本的に, 軟 岩の圧密非排水 (CU)条件のSL-TCTに関する地盤工 学会基準 (JGS 2533) に準拠した. 有効拘束圧は $\sigma{ }_{\mathrm{c}}=$ $0.2,0.4,0.6,0.8,1.0,1.6,3.2 \mathrm{MPa}$ の 種類とし, 合計 7回の ML-TCT を実施した.

このシリーズ 1 の実験で得られる主応力差〜軸ひず み関係および過剩間隙水圧〜軸ひずみ関係を模式的 に図-7 に示す. 軸圧縮 (せん断) /除荷／再圧密のサ 


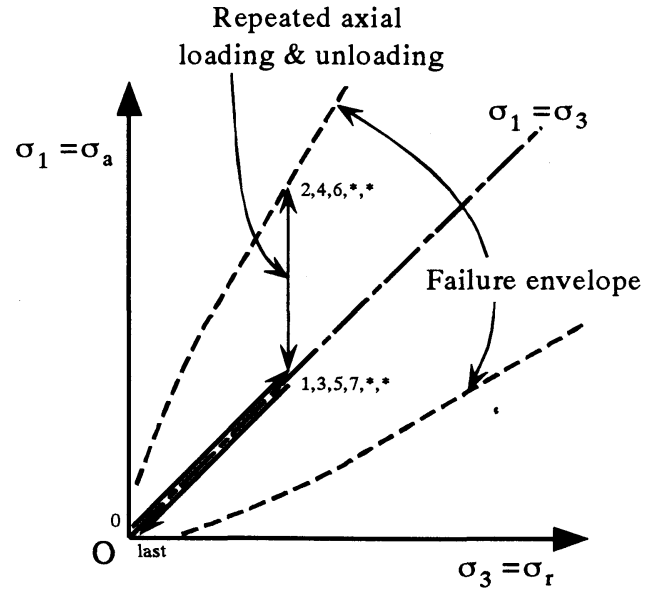

図-6 シリーズ1の実験の方法

イクルは, 軸ひずみを計測する変位計の容量を越える まで(6〜10 回)繰り返して行った. 各載荷段階における ピークの判定は, 確害にせん断強さを把握し, かつ供 試体の損傷を最小限に抑えるため, 荷重計の值が初め て減少(軟化を開始)した時点とした. ピークの判定後, 直ちに軸圧縮 (せん断)を停止して等方応力状態まで 完全にせん断除荷した. そして, 排水状態にして残留し た過剩間隙水圧を消散 (同じ拘束圧で再圧密)させた.

図-7 に示す実験結果より, 各載荷段階に対するせん 断強さ $q_{\mathrm{ML}, \mathrm{i}}$ とピーク時の過剩間隙水圧 $u_{\mathrm{ML}, \mathrm{i}}$, さらに累 積した塑性軸ひずみ $\varepsilon_{\mathrm{a}}{ }_{\mathrm{i}}^{\mathrm{i}}$ を読み取り, MLD モデルの(3) 〜5)の関係が得られる. また, 最初の載荷段階 $(\mathrm{i}=1)$ に対する結果より, SL-TCT に関する(1)と(2)の関係が得 られる. なお, 塑性軸ひずみ $\varepsilon{ }_{\mathrm{a}}^{\mathrm{p}}$ を評価するために重要 な軸ひずみは, ベッディング・エラーの影響を受けない ように, 供試体の側面の異なる高さの圧縮量を計測して 求めた。

a)

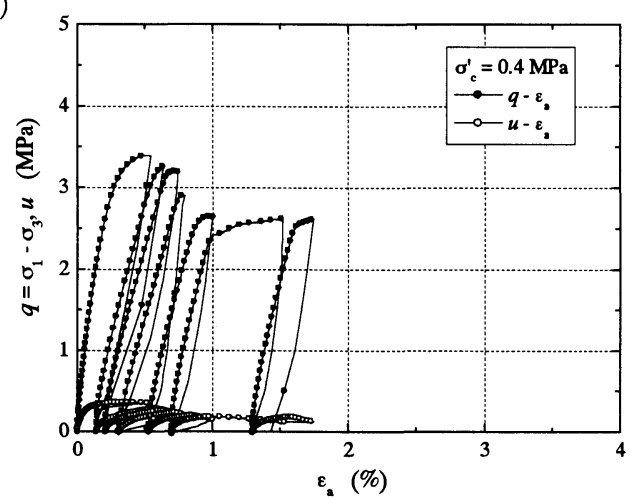

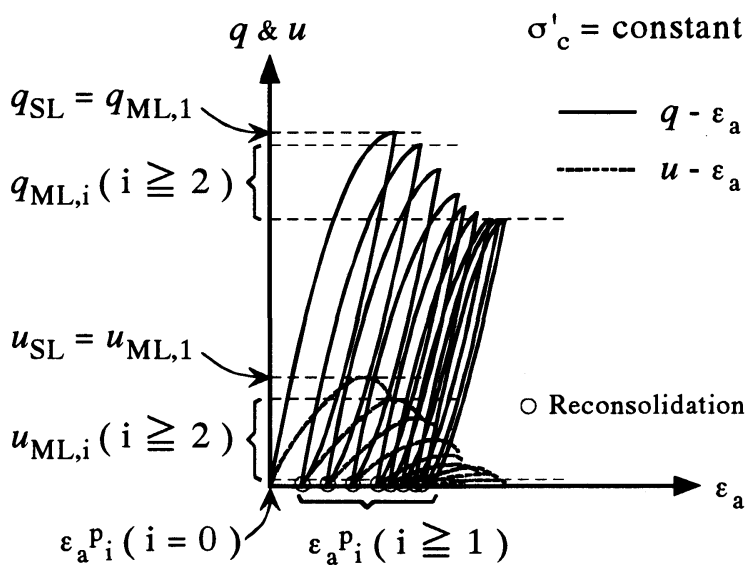

図-7 シリーズ1の実験結果の整理方法

\section{（3）実験の結果}

シリーズ 1 の実験結果のうち, 低い拘束圧 $\left(\sigma^{\prime}{ }_{\mathrm{c}}=0.4\right.$ $\mathrm{MPa})$ と高い拘束圧 $\left(\sigma{ }^{\prime}{ }_{\mathrm{c}}=1.6 \mathrm{MPa}\right)$ のケースについて 主応力差〜軸ひずみ関係および過剩間隙水圧〜軸ひ ずみ関係を図-8に例示する. 拘束圧が低い場合には, 最初の数回の軸圧縮 (せん断)によってせん断強さもピ 一ク時の過剩間隙水圧も大幅に低下し, 忘力履歷によ る損傷の影響が大きい. しかし,この傾向は徐々に収束 する. また, 除荷後に残留した塑性軸ひずみの増分は, 最初の数回は小さいが, 載荷回数が増えてせん断強さ が変わらなくなるとピークが明確でなくなり, 大きく評価 される場合がある.

一方, 拘束圧が高い場合には, 軸圧縮 (せん断) の 回数が増えても塑性軸ひずみが増えるだけで, せん断 強さもピーク時の過剩間隙水圧も 1 回目の載荷段階と 余り変わらず, 応力履歴による損傷の影響は小さい. ま た, 除荷後に残留した塑性軸ひずみの増分は大きく,

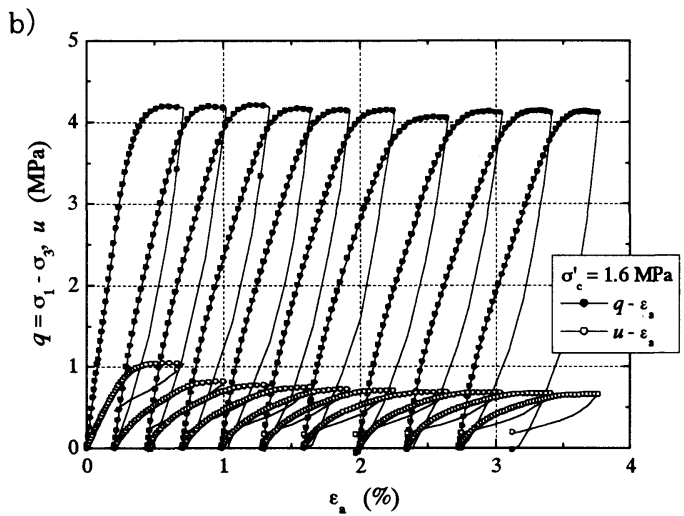

図-8 シリーズ1の実験結果 ( $\mathrm{a}$ :低い拘束圧のケース、 $\mathrm{b}:$ 高い拘束圧のケース) 
軸圧縮 (せん断)の回数が増えても余り変化しない.

\section{（4）シルト岩に対するMLD モテルの作成}

シリーズ1の実験結果より得られたシルト岩に対する MLD モデルの(1)〜(5)の関係を図-9に示す.

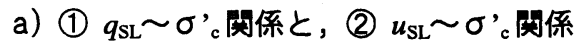

ML-TCT の第1回目の載荷段階の結果より得られた SL-TCT のせん断強さ $q_{\mathrm{SL}}$ とピーク時の過剩間隙水圧 $u_{\mathrm{SL}}$ を推定する関係である. 両者とも有効拘束圧 $\sigma^{\prime}{ }_{\mathrm{c}}$ に 対してほぼ線形に増加する傾向を示した.

モール・クーロンの破壊規準で算出したせん断強度 定数は, 全応力表示の粘着力は $c_{\mathrm{cu}}=1.30 \mathrm{MPa}$, せん 断抵抗角は $\phi_{\mathrm{cu}}=11.4^{\circ}$, 有効応力表示では $c^{\prime}=$

a)

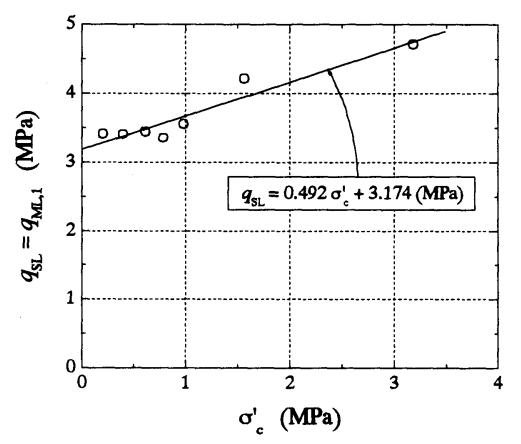

b)

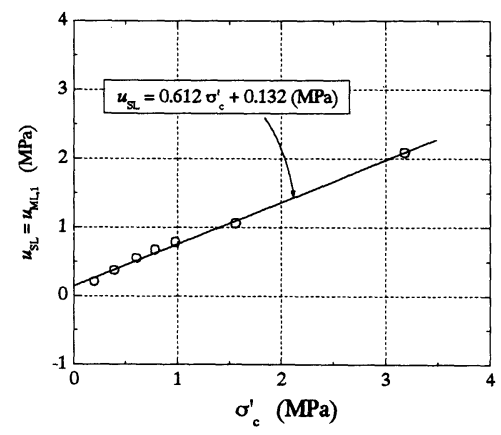

図-9 MLD モデルを構成する5つの関係

$\mathrm{a}:$ (1)の関係 $\left(\mathrm{SL}-\mathrm{TCT} の q_{\mathrm{SL}} \sim \sigma^{\prime} \mathrm{c}\right)$

$\mathrm{b}$ :(2)の関倸 (SL-TCT $の \boldsymbol{u}_{\mathrm{SL}} \sim \sigma^{\prime}{ }_{\mathrm{c}}$ )

$\mathrm{c}$ :(3)の関係 $\left(\mathrm{ML}-\mathrm{TCT} の q_{\mathrm{ML}, \mathrm{i}} / q_{\mathrm{SLi}} \sim \sigma^{\prime}{ }_{\mathrm{c}}, \varepsilon_{\mathrm{a}}{ }_{\mathrm{i}-1-1}\right.$ )

$\mathrm{d}$ :(4)の関係 $\left(\mathrm{ML}-\mathrm{TCT} の u_{\mathrm{ML}, i} / u_{\mathrm{SL}} \sim \sigma{ }_{c}, \varepsilon_{\mathrm{a}}{ }_{\mathrm{i}-1}\right)$

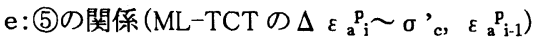

$1.15 \mathrm{MPa}, \phi^{\prime}=20.7^{\circ}$ であった. 従来の結果(全応力 表示では $c_{\mathrm{cu}}=0.85 \mathrm{MPa}, \phi_{\mathrm{cu}}=23.4^{\circ}$, 有効応力表示 では $\left.c^{\prime}=0.64 \mathrm{MPa}, \phi^{\prime}=38.1^{\circ}\right)$ に比較して, せん 断抵抗角は小さく, 粘着力は大きい ${ }^{10}$. この理由は, 非 線形な破壊包絡線に対して, 従来のデータが有効拘束 圧 $1.6 \mathrm{MPa}$ 以下で得られたのに対して, 今回のデータ は, さらに高い有効拘束圧(3.2 MPa まで)のデータが加 わったためである. また, 元々間隙が多い試料であるた めに負のダイレイタンシーを示している.

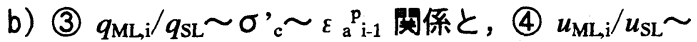

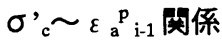

ML-TCT のせん断強さ $q_{\mathrm{ML}, \mathrm{i}}$ とピーク時の過剩間隙水 圧 $u_{\mathrm{ML}, \mathrm{i}}$ を推定する関係である. せん断強さは, 拘束圧

c)

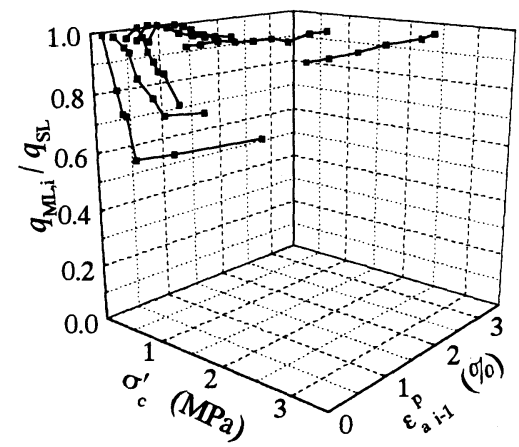

d)

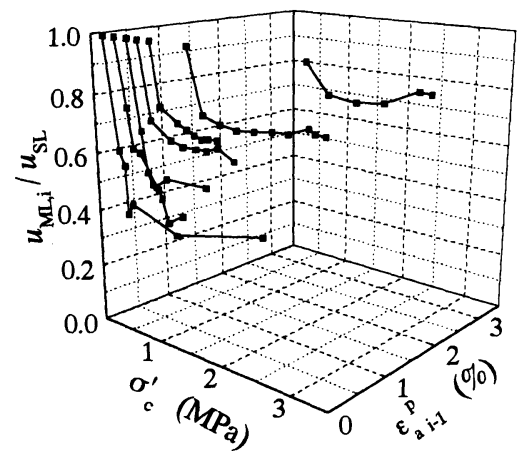

e)

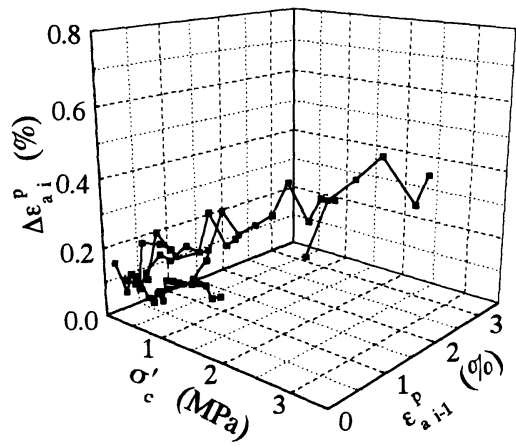


が低い範囲 $\left(\sigma^{\prime}{ }_{c}=0.2,0.4 \mathrm{MPa}\right)$ では塑性軸ひずみと 共に急激に低下して一定值に収束する傾向を示す.し かし，中程度の拘束圧の範囲 $\left(\sigma^{\prime}{ }_{c}^{\prime}=0.6,0.8,1.0\right.$ $\mathrm{MPa}$ )では, 最初の 1,2 回の軸圧縮(せん断)でごくわず かだがせん断強さが増加し, その後, やや減少する傾 向を示寸.さらに高い拘束圧 $\left(\sigma{ }_{c}^{\prime}=1.6,3.2 \mathrm{MPa}\right)$ では, ほとんど変化が見られなかった. 岩石一般の性質である 拘束圧が高くなるに従って破壊が脆性的なものから延 性的なものに変化する傾向と, せん断する毎に残留し た正の過剩間隙水圧を再圧密時に消散させて次第に 密実な構造になって強度が増加する傾向が合わさった 結果であると推測される.

一方, ピーク時の過剩間隙水圧は, 塑性軸ひずみと 共に急激に低下して一定值に収束する傾向を示す.こ の傾向は低拘束圧ほど顕著である。

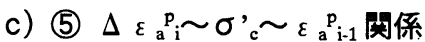

ML-TCT の塑性軸ひずみ増分 $\Delta \varepsilon_{\mathrm{a}}{ }_{\mathrm{i}}^{\mathrm{p}}$ を推定する関 係で, 1 回の軸圧縮 (せん断)／除荷／再圧密のサイク ルで蓄積する新たな損傷の大きさを示す. 高い拘束圧 ほどピーク時の軸ひずみ増分が大きく, 非可逆的な(残 留する)変形分である $\Delta \varepsilon \varepsilon_{\mathrm{a}}{ }_{\mathrm{i}}$ も増加する. 拘束圧が低い 場合には，既に被った塑性軸ひずみ $\varepsilon_{\mathrm{a} i \mathrm{i}-1}^{\mathrm{p}}$ が大きくなる とその増分はやや小さくなるが，拘束圧が高い場合に は減少する傾向が見られなかった。

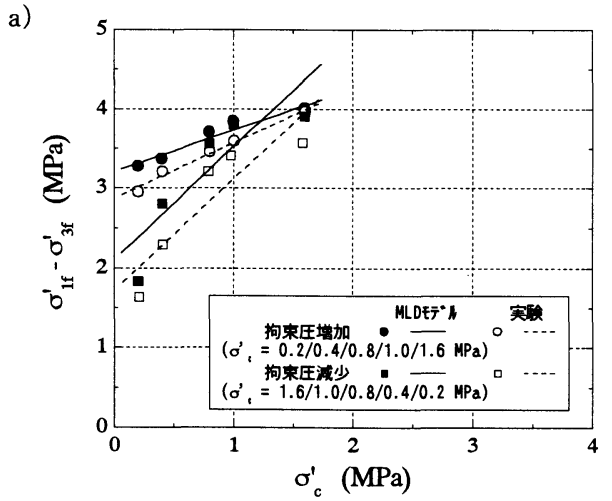

\section{6. シルト岩に対するMLD モテルの検証（シリ ーズ 2 の実験)}

\section{（1）検討の方法}

図-9に示したシルト岩に対するMLD モデルが, 拘束 圧の設定に関してさまざまな ML-TCT をシミュレーショ ンすることができるかどうかを検証する. より具体的には， (3)～(5)の関係が拘束圧の設定方法に依存しないことを 確認することを目的としている. そこで，拘束圧の設定 に関してシリーズ 1 とは異なる 2 種類の ML-TCT 採用 し, 実験(シリーズ2)と MLD モデルを用いたシミュレー ションを行った. 1つは最も一般的な段階的に拘束圧を 高くしていく方法 (拘束圧増加, 図-1 a と図-1 b) で, も う1つは逆に段階的に拘束圧を低くしていく方法(拘束 圧減少, 図-1 c)である。

\section{（2）実験の方法と条件}

実施した2種類の ML-TCT の方法は，拘束圧の設定 以外はシリーズ 1 の実験と同じである. 拘束圧増加のケ 一スでは有効拘束圧を $\sigma{ }^{\prime}{ }_{\mathrm{c}}=0.2 / 0.4 / 0.8 / 1.0 / 1.6 \mathrm{MPa}$ とし, 拘束圧減少のケースでは有効拘束圧を $\sigma{ }^{{ }_{c}}=$ 1.6/1.0/0.8/0.4/0.2 MPa として, それぞれ5回ずつ軸 圧縮(せん断)を行った.

図-9 に示す MLD モデルを用いた ML-TCT のシミュ レーションは, シリーズ2の実験における拘束圧の設定

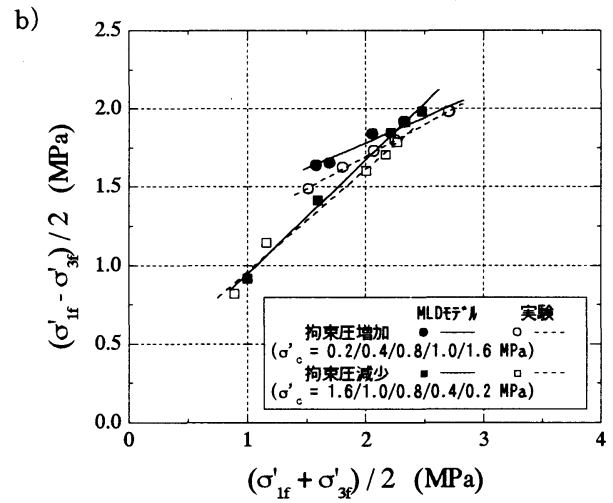

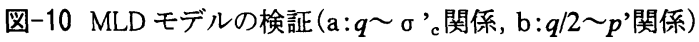

表-2 せん断強度定数の比較 (MLD モデルの検証;シリーズ2の実験)

\begin{tabular}{|c|c|c|c|c|c|c|c|c|c|}
\hline \multirow{2}{*}{ ケース } & \multicolumn{2}{|c|}{ 有効拘束圧 } & \multicolumn{4}{|c|}{ 実験の結果 } & \multicolumn{3}{|c|}{ シミュレーションの結果 } \\
\cline { 2 - 12 } & $\sigma^{\prime}{ }_{\mathrm{c}}(\mathrm{MPa})$ & $\begin{array}{c}c_{\mathrm{ML}} \\
(\mathrm{MPa})\end{array}$ & $\begin{array}{c}\phi_{\mathrm{ML}} \\
(\mathrm{deg} .)\end{array}$ & $\begin{array}{c}c^{\prime}{ }_{\mathrm{ML}} \\
(\mathrm{MPa})\end{array}$ & $\begin{array}{c}\phi^{\prime}{ }_{\mathrm{ML}} \\
(\mathrm{deg} .)\end{array}$ & $\begin{array}{c}c_{\mathrm{ML}} \\
(\mathrm{MPa})\end{array}$ & $\begin{array}{c}\phi_{\mathrm{ML}} \\
(\mathrm{deg} .)\end{array}$ & $\begin{array}{c}c^{\prime}{ }_{\mathrm{ML}} \\
(\mathrm{MPa})\end{array}$ & $\begin{array}{c}\phi^{\prime}{ }_{\mathrm{ML}} \\
(\mathrm{deg} .)\end{array}$ \\
\hline 拘束圧増加 & $0.2 / 0.4 / 0.8 / 1.0 / 1.6$ & 1.10 & 15.0 & 0.94 & 24.9 & 0.98 & 12.1 & 1.19 & 19.1 \\
\hline 拘束圧減少 & $1.6 / 1.0 / 0.8 / 0.4 / 0.2$ & 0.51 & 25.7 & 0.40 & 41.0 & 0.60 & 26.6 & 0.31 & 46.8 \\
\hline
\end{tabular}


に従って図-5 のフローで計算した. なお, (1)と(2)の関係 は図-9a と図-9b に示すように実験データを直線回㷌し たものを利用し, (5)の関係 (図-9e) は実験データのばら つきが大きいので各拘束圧に対して直線回帰した関係 を用いた.一方, (3)と(4)の関係(図-9c と図-9d) は各拘 束圧に対する関係が比較的に滑らかな曲線を描いてい るので, 実験データの間を線形補間して対応する值を 読み取った。

\section{(3) 検討の結果}

実験の結果と, MLD モデルを用いたシミュレーション の結果を図-10 に比較する. 図-10a は有効拘束圧 $\sigma{ }_{\mathrm{c}}$ に対してピーク時の軸差応力 $q=\sigma{ }^{\prime}{ }_{1 \mathrm{f}}-\sigma{ }^{\prime}{ }_{3 \mathrm{f}}$ をプロット したもので, 図-10 b はピーク時の平均主応力 $p^{\prime}=$ $\left(\sigma^{\prime}{ }_{1 \mathrm{f}}+\sigma^{\prime}{ }_{3 \mathrm{f}}\right) / 2$ に対して最大せん断応力 $q / 2=\left(\sigma^{\prime}{ }_{1 \mathrm{f}}-\right.$ $\left.\sigma{ }^{\prime}{ }_{3 f}\right) / 2$, すなわちモールの応力円の頂点をプロットした ものである.

図-10aを見ると，せん断強さに関しては、拘束圧増 加のケースと拘束圧減少のケースともシミュレーション結 果が実験の結果をやや過大評価しているが, 拘束圧の 変化に対する傾向は両ケースの相違を再現できている ことが分かる. また, ピーク時の応力值を比較する図-10

a)

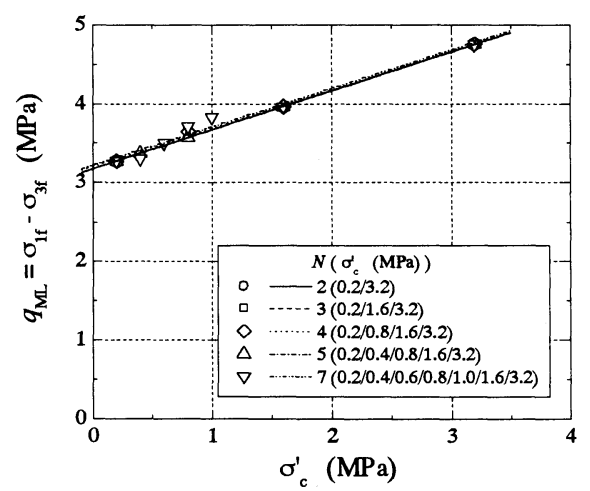

bを見ると, 両ケースとも実験とシミュレーションの結果 がほぼ一致している. また, せん断強度定数を比較した 表-2を見ても，MLDモデルが実験結果を再現する能力 が高いことが分かる. 若干の相違は試料のばらつきが 原因と推測され，MLD モデルが拘束圧の設定に関して さまざまな ML-TCT をシミュレーションすることが可能で あると判断した.

\section{7. 多段階載荷の三軸圧縮試験のシミュレーション}

拘束圧の設定に関してさまざまな ML-TCT をシミュレ ーションできることが示されたので,この MLD モデルを 利用して, ML-TCT において軸圧縮 (せん断)を行う拘 束圧の設定数と順序について検討する.

\section{（1）軸圧縮（せん断）を行う拘束圧の順序}

低い拘束圧から高い拘束圧一と段階的に上げていく 方法 (図-1 a と図-1b), 高い拘束圧から低い拘束圧一 段階的に下げていく方法 (図-1c), さらにランダムに拘 束圧を設定する方法 (図-1d (ランダム1) と図-1e (ラン ダム2))の合計 4 種類のケースを比較した. 軸圧縮 (せ

b)

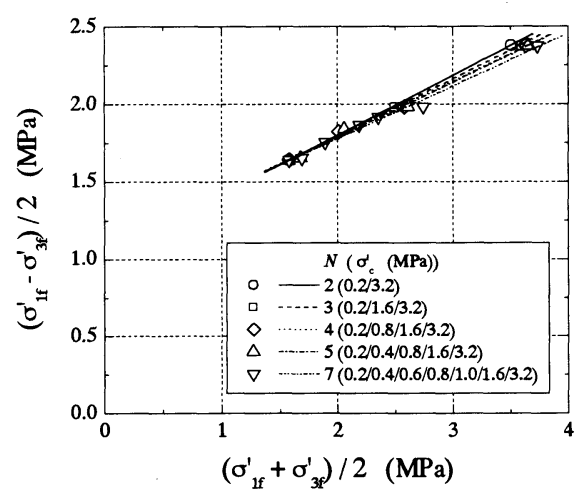

図-11 軸圧縮 (せん断)を行う拘束圧の順序の検討 $\left(\mathrm{a}: q \sim \sigma^{\prime}{ }_{\mathrm{c}}\right.$ 関係, $\mathrm{b}: q / 2 \sim p$ '関係)

表-3 せん断強度定数の比較(軸圧縮 (せん断)を行う拘束圧の順序)

\begin{tabular}{|c|c|c|c|c|c|c|}
\hline \multirow{2}{*}{\multicolumn{2}{|c|}{ ケース }} & 有効拘束圧 & \multicolumn{2}{|c|}{ 全応力表示 } & \multicolumn{2}{|c|}{ 有効応力表示 } \\
\hline & & $\sigma^{\prime}{ }_{c} \quad(\mathrm{MPa})$ & $\begin{array}{c}c_{\mathrm{SL}}, c_{\mathrm{ML}} \\
(\mathrm{MPa})\end{array}$ & $\begin{array}{c}\phi_{\mathrm{SL}}, \phi_{\mathrm{ML}} \\
\text { (deg.) }\end{array}$ & $\begin{array}{c}c^{\prime}{ }_{\mathrm{SL}}, c^{\prime}{ }_{\mathrm{ML}} \\
(\mathrm{MPa})\end{array}$ & $\begin{array}{l}\phi{ }^{\prime}{ }_{\mathrm{SL}}, \phi{ }^{\prime} \mathrm{ML} \\
\text { (deg.) }\end{array}$ \\
\hline \multicolumn{2}{|c|}{ SL-TCT } & $0.2,0.4,0.8,1.6,3.2$ & 1.30 & 11.4 & 1.15 & 20.7 \\
\hline \multirow{4}{*}{ ML-TCT } & 拘束圧増加 & $0.2 / 0.4 / 0.8 / 1.6 / 3.2$ & 1.30 & 11.5 & 1.09 & 23.1 \\
\hline & 拘束圧減少 & $3.2 / 1.6 / 0.8 / 0.4 / 0.2$ & 0.77 & 18.5 & 0.44 & 36.3 \\
\hline & ランダム1 & $0.2 / 3.2 / 0.4 / 1.6 / 0.8$ & 1.12 & 13.8 & 0.85 & 27.2 \\
\hline & ランダム2 & $3.2 / 0.2 / 1.6 / 0.4 / 0.8$ & 0.77 & 18.5 & 0.47 & 35.7 \\
\hline
\end{tabular}


ん断)の回数は5回とし, 有効拘束圧は $0.2,0.4,0.8$, 1.6, 3.2 MPa の5つとした.

図-11 a には有効拘束圧 $\sigma^{\prime}{ }_{\mathrm{c}}$ に対してピーク時の軸 差応力 $q=\sigma^{\prime}{ }_{1 \mathrm{f}}-\sigma{ }^{\prime}{ }_{3 \mathrm{f}}$ をプロットしたもので, 図-11bに はピーク時の平均主応力 $p^{\prime}=\left(\sigma^{\prime}{ }_{1 \mathrm{f}}+\sigma{ }^{\prime}{ }_{3 \mathrm{f}}\right) / 2$ に対して

a)

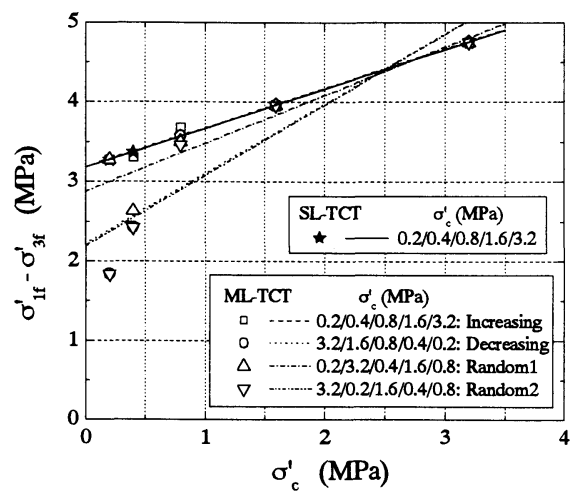

最大せん断応力 $q / 2=\left(\sigma^{\prime}{ }_{1 \mathrm{f}}-\sigma^{\prime}{ }^{\prime}{ }_{3 \mathrm{f}}\right) / 2$, すなわちモー ルの忘力円の頂点をプロットしたものである. さらに, せ ん断強度定数を表-3に比較した.

シミュレーションの結果より, 軸圧縮 (せん断)を行う拘 束圧の順序によってせん断強さに与える影響が異なる

b)

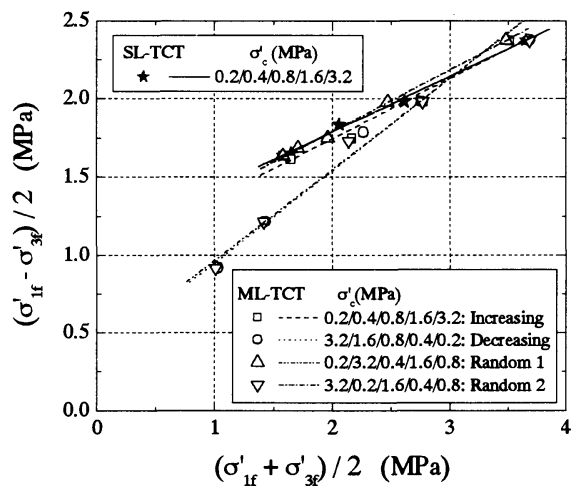

図-12 軸圧縮(せん断)を行う拘束圧の設定数の検討 $\left(\mathrm{a}: q \sim \sigma{ }^{\prime}{ }_{\mathrm{c}}\right.$ 関係, $\mathrm{b}: q / 2 \sim p$ 関係)

表-4 せん断強度定数の比較 (軸圧縮 (せん断)を行う拘束圧の設定数)

\begin{tabular}{|c|c|c|c|c|c|c|}
\hline \multirow{2}{*}{\multicolumn{2}{|c|}{ ケース }} & 有効拘束圧 & \multicolumn{2}{|c|}{ 全応力表示 } & \multicolumn{2}{|c|}{ 有効応力表示 } \\
\hline & & $\sigma_{c}^{\prime} \quad(\mathrm{MPa})$ & $\begin{array}{c}c_{\mathrm{SL}}, c_{\mathrm{ML}} \\
(\mathrm{MPa})\end{array}$ & $\begin{array}{c}\phi_{\mathrm{SL}}, \phi_{\mathrm{ML}} \\
\text { (deg.) }\end{array}$ & $\begin{array}{c}c_{\mathrm{SL}}^{\prime}, c^{\prime}{ }_{\mathrm{ML}} \\
(\mathrm{MPa})\end{array}$ & $\begin{array}{c}\phi^{\prime}{ }_{\mathrm{SL}}, \phi{ }_{\mathrm{ML}} \\
\text { (deg.) }\end{array}$ \\
\hline \multicolumn{2}{|c|}{ SL-TCT } & $0.2,0.4,0.8,1.6,3.2$ & 1.30 & 11.4 & 1.15 & 20.7 \\
\hline \multirow{5}{*}{ ML-TCT } & 2 回 & $0.2 / 3.2$ & 1.30 & 11.4 & 1.11 & 22.6 \\
\hline & 3 回 & $0.2 / 1.6 / 3.2$ & 1.30 & 11.4 & 1.14 & 21.6 \\
\hline & 4 回 & $0.2 / 0.8 / 1.6 / 3.2$ & 1.32 & 11.2 & 1.16 & 20.8 \\
\hline & 5 回 & $0.2 / 0.4 / 0.8 / 1.6 / 3.2$ & 1.30 & 11.4 & 1.15 & 20.9 \\
\hline & 7 回 & $0.2 / 0.4 / 0.6 / 0.8 / 1.0 / 1.6 / 3.2$ & 1.31 & 11.5 & 1.17 & 19.8 \\
\hline
\end{tabular}

a)

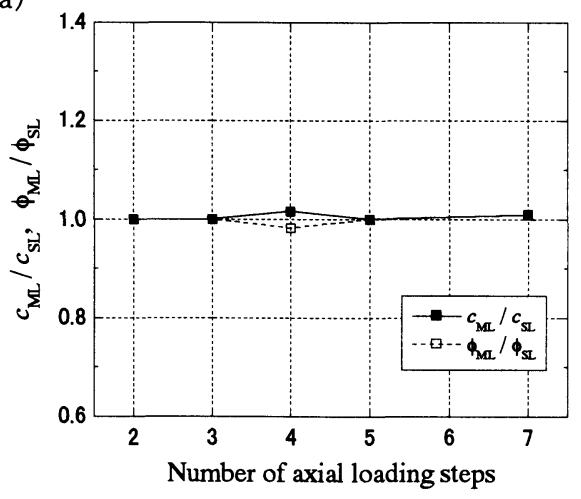

b)

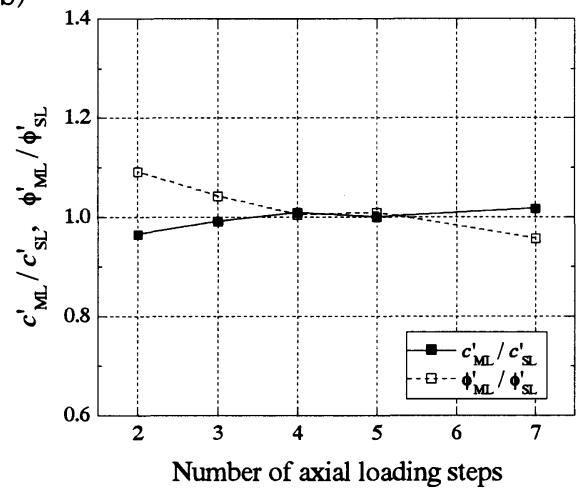

図-13 軸圧縮 (せん断)を行う拘束圧の設定数に関するせん断強度定数 ( $\mathrm{a}$ :全応力表示, $\mathrm{b}$ :有効応力表示) 
ことが読み取れる. そして, 低い拘束圧から高い拘束圧 一と段階的に上げていく ML-TCT が最も SL-TCT に近 い結果を与えることが分かる. 他のケースは損傷の影響 が大きく, いずれも粘着力を過小評価し, 逆にせん断抵 抗角を過大評価する傾向にある. 特に, 最も低い拘束 圧は損傷の影響でせん断強さが大幅に低下するので (図-9cの(3)の関係を参照), 損傷が蓄積しないうちに (早い載荷段階で) 低拘束圧の軸圧縮 (せん断)を実施 する必要がある.

\section{（2）軸圧縮（せん断）を行う拘束圧の設定数}

拘束圧の順序について最も適切と判断された低い拘 束圧から高い拘束圧へと段階的に上げていく方法 (図 $-1 \mathrm{a}$ の図-1 b ) に関して, 軸圧縮 (せん断) の回数が2, $3,4,5,7$ 段階のケースを比較した. 有効拘束圧は 0.2 , $0.4,0.6,0.8,1.0,1.6,3.2 \mathrm{MPa}$ のつで, 最小と最大の 拘束圧 (0.2 MPa と $3.2 \mathrm{MPa})$ を含んでなるべく等間隔に なるように設定した.

図-12 a には有効拘束圧 $\sigma^{\prime}{ }_{\mathrm{c}}$ に対してピーク時の軸差 応力 $q=\sigma^{\prime}{ }_{1 \mathrm{f}}-\sigma{ }^{\prime}{ }_{3 \mathrm{f}}$ をプロットしたもので, 図-12bには ピーク時の平均主応力 $p^{\prime}=\left(\sigma{ }^{\prime}{ }_{1 \mathrm{f}}+\sigma{ }^{\prime}{ }_{3 \mathrm{f}}\right) / 2$ に対して最 大せん断応力 $q / 2=\left(\sigma^{\prime}{ }_{1 \mathrm{f}}-\sigma^{\prime}{ }^{3 \mathrm{f}}\right) / 2$, すなわちモール の応力円の頂点をプロットしたものである. さらに, 求め られたせん断強度定数の值を表-4 に, ML-TCT による せん断強度定数を SL-TCT による值で無次元化した結 果を図-13に示す.

図-12 a と図-13aを見ると, せん断強さや全応力表 示のせん断強度定数に関しては、軸圧縮 (せん断)の 回数の影響は小さい. しかし, 図-12b と図-13bに示 すピーク時の応力值や有効応力表示のせん断強度定 数を見ると, 軸圧縮 (せん断) の回数が増えて損傷が蓄 積すると, 粘着力が小さく, 逆にせん断抵抗角が大きく なる傾向がある. 高い拘束圧においてせん断強さは損 傷の影響を受けないが, ピーク時の過剩間隙水圧は損 傷の増大と共に低下するので(図-9dの(4)の関係を参 照), 有効応力で整理する場合に影響が表れることにな る. このシルト岩の場合, 軸圧縮 (せん断)の回数は4な いし5回が適切である.

\section{8. 結論}

少ない供試体で単段階載荷の三軸圧縮試験 (SL-TCT) と同等のせん断強度特性を評価することが できると期待される多段階載荷の三軸圧縮試験 (ML-TCT)は, 時間的にも経済的にも有利な手法であ る. しかし, 軸圧縮 (せん断)の繰り返しによって供試体 に損傷が蓄積して, 発揮されるせん断強さが低下寸るメ
カニズムが明らかではないため, SL-TCT の代替方法と して確立されてはいない. そこで, ML-TCTをシミュレー ションすることができる数理モデルを提案し, 軸圧縮 (せ ん断)を行う拘束圧の設定数之順序について検討し，以 下の結論を得た.

（1） ML-TCT をシミュレーションする数理モデルとして, 供試体に蓄積する損傷を塑性軸ひずみで代表させる 多段階載荷損傷モデル(MLD モデル)を提案した.

（2）シルト岩を用いて一連の ML-TCT(シリーズ1の実 験)を実施し, その具体的なモデルを作成した. そして, 拘束圧の設定に関してシリーズ1とは異なる ML-TCT (シリーズ2の実験)を実施し，MLD モデルの妥当性を 検証した.

（3）シルト岩について作成した MLD モデルを利用し て, 軸圧縮 (せん断)を行う拘束圧の設定数と順序を変 えた ML-TCT をシミュレーションし, 軸圧縮(せん断)の 回数を4ないし5回とし, 低い拘束圧から高い拘束圧一 と段階的に上げていく ML-TCT が適切であることを示し た.

上記の結論は, 固結度が低く負のダイレイタンシー特 性を示すシルト岩について導かれたものである. 塑性軸 ひずみや過剩間隙水圧の出方や破壊の特性(脆性ま たは延性)によって, 最適な拘束圧の設定条件は異な る傾向を示すかもしれない. 今後, 幅広い岩種に対して MLD モデルの適用性を検討し, ML-TCT の最適な試 験方法を確立する必要がある. さらに, MLD モデルを 用いることで, ML-TCT によって得られたせん断強さか ら, 本来の SL-TCT のせん断強さを推定する手法の検 討も可能となろう.

\section{参考文献}

1）地盤工学会基準:岩石の UU 条件(JGS 2531), 軟岩の CU 条件 (JGS 2532 \& 2533), 軟岩の CD 条件(JGS 2534) の三軸圧縮試験方法.

2) Kovari, K. and Tisa, A.: Multiple failure state and strain controlled tests, Rock Mechanics, Vol.7, No.1, pp.17-33, 1975.

3) Chang, N.Y. and Jumper, A.L.: Multiple-stage triaxial test on oil shale, Proc. $19^{\text {th }}$ US Rock Mechanics Sym., pp.520-527, 1978.

4）赤井浩一, 大西有三, 李 徳河: 多段階三軸圧縮試験とそ の飽和軟岩への適用について, 土木学会論文報告集, 第 311 号, pp.93-102, 1981.

5）木山 保, 中田雅夫, 原 正之, 佐々木勝司: 自動化され た多段階三軸圧縮試験による数種の岩石の強度特性, 第 48 回土木学会年次学術講演会, pp.1304-1305, 1993.

6）阿部大志, 田野久貴, 渡辺英彦: 岩石の多段階三軸圧縮 試験に関する基礎実験, 第 52 回土木学会年次学術講演 
会, pp.552-553, 1997.

7）田野久貴, 田辺英彦, 阿部大志:AEを用いた岩石の多段 階三軸圧縮試験の試み, 第 10 回岩の力学国内シンポジ ウム, pp.683-688, 1998.

8）伊藤達也:大谷石を用いた多段階三軸圧縮試験につい て, 第 35 回地盤工学研究発表会, pp.1003-1004, 2000.

9）木村 誠, 谷 和夫:シルト岩を用いた多段階载荷損傷モ
デルの適用性の検討, 第11回岩の力学国内シンポジウム, $\mathrm{A} 02,6 \mathrm{p}, 2002$.

10) 谷 和夫, 池見元宣:三軸圧縮試験で見られた均質な軟 岩のせん断挙動に関する寸法効果, 第 11 回岩の力学国 内シンポジウム, A14, 6p, 2002.

\title{
DEVELOPMENT OF A MODEL FOR MULTIPLE-STEP LOADING TRIAXIAL COMPRESSION TEST AND INVESTIGATION OF ITS APPLICABILITY
}

\author{
Makoto KIMURA, Kazuo TANI and Tetsuji OKADA
}

Several specimens should be prepared when strength characteristics of rock is evaluated by conventional single-step loading triaxial compression tests. On the contrary, multiple-step loading triaxial compression test, hereafter denoted as ML-TCT, is advantageous as shear strengths for different confining pressures can be obtained on a single specimen. ML-TCT, however, is not established as a standard test method, because of possible under-estimation of shear strengths due to accumulated damage by repeated axial compression steps. In this study, Multiple-step loading damage model is proposed to simulate ML-TCT properly, and appropriate number and procedure of axial compression steps for ML-TCT are investigated. 